\title{
Sexuální zdrženlivost a celibátní praxe v náboženstvích světa
}

\author{
Věra Bártová \\ Ústav antropologie, Př́rodovědecká fakulta, Masarykova univerzita, Kotlářská 267/2, 61137 Brno, Česká republika \\ Do redakce doručeno 12. března 2018; k publikaci přijato 13. června 2018
}

\section{SEXUAL RESTRAINT AND CELIBACY PRACTICE IN WORLD RELIGIONS}

\begin{abstract}
The idea of celibacy is intrinsically tied to the Roman Catholic Church in the Central European region. It is a widely discussed topic especially in relation to clergymen and contrary to popular belief it has been discussed since long ago. Disputes and clashes regarding the question of whether or not should be celibacy amongst clergy mandatory have been present throughout the entire history of Christianity. Nevertheless, Christianity is not the only major world religion to uphold the principles of celibacy. The practice of celibacy is also common in Buddhism and can also be observed in Hinduism. On the contrary, Judaism and Islam oppose celibacy, even though it has been implemented in various forms in these religions throughout history as well. Every religion displays a certain tendency to regulate the sexual behavior of its followers, sexual restraint being one of the ways in which this tendency manifests. Although numerous studies that analyze religion and sexuality from many perspectives have been conducted, the relationship between religion, celibacy and sexual restraint is often omitted and discussed only superficially. That is why this study aims to establish an overview of the relationship between the major world religions and sexual restraint as well as celibacy.
\end{abstract}

KEY WORDS celibacy; religion; restraint; ascetism; faith

ABSTRAKT Celibát je $\mathrm{v}$ dnešní době v našich zeměpisných šířkách centrální Evropy neodmyslitelně spjat $\mathrm{s}$ římskokatolickou církví. $\mathrm{V}$ této církvi je velmi diskutovaným tématem ve spojitosti s kněžími a to nejen v posledních letech, jak by se mohlo zdát. Diskuze a boje v otázce povinnosti či dobrovolnosti celibátu kléru se vedou napříc historií celého křestanství. Křestanství však není jediným světovým náboženstvím se zavedenou institucí celibátu. Celibátní praxe je běžná i v buddhismu a také se s ní lze setkat v hinduismu. Naopak judaismus a islám se k celibátu staví odmítavě, přesto i v nich se v průběhu historie objevuje určitá jeho forma. Každé náboženství má také snahu určitým způsobem usměrňovat sexuální chování svých vyznavačů, jedním z prostředků je i sexuální zdrženlivost. Přestože se mnoho studií věnuje náboženství a sexualitě z nejrůznějších perspektiv, vztah náboženství, celibátu a sexuální zdrženlivosti bývá často opomíjen a zmiňován pouze okrajově. Tato studie se proto snaží přinést základní přehled vztahu světových náboženství k sexuální zdrženlivosti a celibátu.

KLÍČOVÁ SLOVA celibát; náboženství; zdrženlivost; asketismus; víra

\section{ÚVOD}

Podle Junga je člověk „ přirozeně náboženský“ a má tendenci své náboženství stále rozvíjet. Pojem náboženství označuje vztah člověka k Bohu či nadpřirozené síle, která jej přesahuje, přičemž existuje množství teorií o jeho původu (Bowie 2008, s. 36-39; iEncyklopedie; Jung 1994). Stejně tak je i sexualita nedílnou součástí života každého jedince. Vztahu náboženství a sexuality se věnuje mnoho studií, avšak vztah náboženství a zdrženlivého chování bývá středem zájmu jen v nemnoha př́ípadech. Jedinou výjimku tvoří celibát kněží římskokato- lické církve, $\mathrm{k}$ tomuto tématu lze dohledat velké množství publikací (např. Heid 2000; Parish 2010; Phipps 2004; Selin 2016; Stickler 1995). Souhrnně se vztahu náboženství a celibátu věnuje např. Olson (2008). Tato studie se snaží představit a shrnout základní přístupy světových náboženství k sexuálně zdrženlivému a celibátnímu prožívání náboženství. Jednotlivých náboženství je velké množství a ještě větší množství je jejich nejrůznějších odnoží vzniklých v průběhu staletí, není proto možné vměstnat toto obrovské množství informací do jednoho článku. Proto budou v tomto příspěvku představeny přístupy těch nejrozšířenějších náboženství. 


\section{KŘESŤANSTVÍ}

Křest’anství, jež bývá v souvislosti s celibátem uváděno nejčastěji, patří mezi monoteistická náboženství a jeho počátek, datovaný do období 1.-2. století n. 1., je spojován s Ježíšem Kristem. Učení Ježíše Krista bylo po jeho ukřižování a zmrtvýchvstání šířeno apoštoly, jeho učedníky. Velkou zásluhu na rozšíření křestanství do centra římské říše měl Pavel z Tarzu. Zpočátku byli první následovníci Ježíše považování spíše za židovskou sektu a jejich víra nebyla brána jako samostatné náboženství. Množství stoupenců pocházelo $\mathrm{z}$ řad otroků a utiskovaných, které si vznikající náboženství získalo díky novému pojetí koncepce posmrtné spásy zaručené obětí Ježíše Krista. Pro jejich odlišení byl až později, poprvé v Antiochii, použit pojem „křestan“ (Sk 11,26). Posvátným textem křest’anů se stala Bible obsahující Starý Zákon a Nový Zákon. Prvotní církevní společenství byla spravována kolektivně a neexistovala $\mathrm{v}$ nich žádná postava kultického kněze, ta se začala objevovat až v pozdějších letech (3. st.). S rozvojem pozice kultického kněžství souvisely i změny $\mathrm{v}$ hierarchii společnosti. $\mathrm{V}$ rámci vyčleňování kněží od ostatních členů společenství docházelo i k postupnému rozvoji a zavádění instituce celibátu (Denzler 1999, s. 120; Denzler 2000, s. 7; Holland 2008, s. 67, 72-73; iEncyklopedie; Malina - Pardyová - Pavelka, 2011).

Původní jednotné křestanství se v průběhu staletí začalo rozdělovat na množství církví, mezi něž patří například církev římskokatolická, řeckokatolická a různé církve pravoslavné, mimo nich pak lze ještě uvést i církev arménskou či koptskou a nelze zapomenout na církve protestantské (Malina - Pardyová - Pavelka, 2011). ${ }^{1}$

\section{Římskokatolická církev}

V roce 1054 se křestanství rozdělilo na Západní a Východní církve. Římskokatolická církev je z nich všech nejpočetnější. V jejím čele stojí papež, který je zástupcem Ježíše Krista na Zemi (iEncyklopedie).

Celibát a sexuální zdrženlivost jsou spjaty s římskokatolickou církví nejvíce ze všech křestanských církví a celibát je zde povinný pro část jejich představitelů. Povinným pro všechny církevní představitele začal být celibát ale až od 12. století, konkrétně od roku 1139 (Denzler 2000, s. 29). Pro opodstatnění celibátu se hledají důkazy v Ježíšově životě a jeho učení. V této souvislosti bývá citována tato pasáž z Bible: „Někteří nežijí v manželství, protože jsou k tomu od narození nezpiosobilí; jiní nežijí v manželství, protože je nezpiosobilými učinili lidé; a někteři nežijí v manželství, protože se ho zřekli pro království nebeské. Kdo může pochopit, pochop.“ (Mt 19,12). Je pravdou, že Ježíš v celibátu žil a tento stav pokládal za vhodnější než manželství, avšak nikomu ho nenařizoval. Stejně tak mezi jeho učedníky lze nalézt jak ženaté apoštoly (Petr), tak i za-

1 Historie křestanství je velice bohatá a nelze ji zde obsáhnout v pár řádcích, pro zájemce věnující se problematice hlouběji doporučuji např.: MacCulloch, Diarmaid (2011): Christianity: the first three thousand year. Penguin Books. 1184 s. ISBN 978-0143118695. stánce celibátu (Pavel), kteří celibát doporučovali jako vhodnější formu života (Holland 2008, s. 65-68; Cholij 1993). Ve 2. století se nově začal objevovat asketický způsob života (život $\mathrm{v}$ ústraní a tvrdém odř́kání, $\mathrm{k}$ němuž náleží i celibát), $\mathrm{k}$ jehož masivnímu rozvoji začalo docházet ve 4 . století. V té době se začali objevovat první osamoceně žijící asketičtí poustevníci (eremité) a v komunitách se shromaždující koinobité, jež byli počátkem mnišských společenstev. $\mathrm{V}$ počátcích rozvoje askeze byla rozšířena také kastrace, která napomáhala žít ctnostným životem, avšak v pozdějších stoletích již byla zakázána. Od 6 . století se na území Západní církve začíná šírit klášterní způsob života vycházející $\mathrm{z}$ východního asketismu. Se vzrůstajícím počtem klášterů však docházelo $\mathrm{v}$ některých $\mathrm{z}$ nich i ke značnému úpadku morálky. Namísto, aby kláštery byly útočištěm zbožných mnichů a mnišek žijících v celibátu, stávaly se centrem peněžních machinací, politických intrik a sexuálních skandálů. Ke změně začalo docházet v 10 . století, kdy se ve francouzském klášteře Cluny započala reforma, která se postupně rozšírila na celou církev a byla završena Gregoriánskými reformami v 11. století. Následně byly ve 12 . století I. a II. lateránským koncilem vyhlášeny rozhodující kánony zakazující klerikům vstupovat do manželství (Abbottová 2005, s. 111-112, Blumenthal 2008, s. 61, 63; Denzler 2000, s. 7-10, Denzler 1999, s. 30-31; 120; Holland 2008, s. 71; Cheatham 2008, s. 94).

Prosazování povinného celibátu trvalo nejméně ještě další století. Během této doby bylo nezbytné zdiskreditovat stávající manželky kněží. Z žen, které při vstupu do manželství přijímaly speciální požehnání a titul presbyteria či saccerdotissa, se staly nežádoucí pomocnice dábla, které svojí sexualitou znesvěcovaly duchovní i oltář. Jako důvod proti manželkám bylo jednak uváděno ono znečištování sexualitou a také to, že manželky a děti připravovaly církev o majetek. Po odstranění nyní nežádoucích manželek kleriků bylo potřeba vyplnit toto uvolněné místo vhodnou náhradou vedoucí ke zbožnějšímu životu. Tou se ukázala být Panna Maria a její kult, který díky tomu strmě vzrostl. Velice pravděpodobně však došlo i k nárůstu homosexuálního chování (Elliott 1999, s. 82-84; 106-108). I přes tvrdé postihy docházelo poměrně často $\mathrm{k}$ narušování celibátu a těmito prohřešky se museli zabývat na nejrůznějších koncilech a synodách (Denzler 2000, s. 30-32, 57). Začaly se objevovat snahy o zrušení či zdobrovolnění povinného celibátu (Denzler 2000, s. 103, 105, 107-108).

Církev vydala v průběhu historie mnoho dokumentů týkajících se celibátu, z nichž lze např́íklad uvést několik písemností papeže Pavla VI. Dekret Optatam Totius pojednává o výchově ke kněžství. Mimo jiné nabádá bohoslovce k přijetí povinného celibátu jako Božího daru (Pavel VI. 1965a, IV. kapitola). Následoval dekret Presbyterorum ordinis, podle něhož mohou duchovní díky celibátu lépe následovat Ježíše Krista a plněji se věnovat službě Bohu. Je zde opět potvrzen význam celibátu jako povinná a neoddělitelná součást kněžského povolání (Pavel VI. 1965b, 3. kapitola). Třetím důležitým dokumentem Pavla VI. v otázce celibátu je encyklika Sacerdotalis caelibatus, která předkládá jak argumenty uváděné proti povinnému celibátu, tak i argumenty pro jeho podporu (Pavel VI. 1967). Otázka povinného celibátu duchovních, zejména kněží, je 
stále aktuální. Nejnověji rozvírilo diskuzi vyjádření, že papež František v březnu roku 2017 připustil možnost, svěcení ženatých mužů na kněze (Baret 2017). Celibátu se také věnuje i část Katechismu katolické církve a to jak v souvislosti s kněžským povoláním, tak i v souvislosti s manželstvím a šestým přikázáním (Katechismus katolické církve 2002, 915, 1579, 1580, 1599, 1658, 2349). Kromě povinného celibátu duchovních a řádových sester a bratř́, se můžeme setkat i s požadavkem na laiky, aby byla sexualita konzumována až po uzavření manželství. ${ }^{2}$

\section{Pravoslavné církve}

Počátek pravoslaví lze hledat $\mathrm{v}$ době velkého schizmatu $\mathrm{v}$ roce 1054, kdy se křestanství rozdělilo na Západní a Východní církve. Pravoslaví, které klade důraz na tradici církevních otců a prvních koncilů, je tvořeno patnácti autokefálními (samostatnými) a dvěma autonomními východními církvemi. Neexistuje žádná instituce, která by měla moc nad všemi pravoslavnými církvemi a každá církev je zodpovědná za svou vlastní správu. Přesto všechny pravoslavné církve uznávají zvláštní roli cařihradského patriarchy, který zaručuje správný chod koncilních prací, avšak nemá moc zasahovat do samosprávy ostatních pravoslavných církví. Na našem území působí Pravoslavná církev v českých zemích a na Slovensku, která navazuje na tradici Konstantina a Metoděje z 9. století (Hackel 2010, s. 715; Roberson 2010, s. 717; Vojtíšek 2004, s. 28-29). ${ }^{3}$

$\mathrm{V}$ pravoslaví je celibát spjat $\mathrm{s}$ mnišstvím, kde je přijímán s velkou úctou. Mnišství se řídí pravidly sestavenými Bazilem Velikým (330-379). Za centrum mnišství, které má v pravoslaví velkou tradici, je považován poloostrov Athos, jež má v Řecku autonomní status jako mnišská republika. Celibát je součástí odříkavého stylu života a společně s chudobou a poslušností tvoří základ askeze. Mniši postupně během let skládají dvoje hlavní sliby. Nejprve po dlouhé zkušební době mnich skládá sliby a obdrží mnišský oděv a nové jméno, malá schima. Později následuje velká schima, plnohodnotné mnišství, kdy se skládají opětovně sliby a přidávají se další prrísnější a mění se i mnišský oděv. V pravoslaví existuje několik forem mnišství počínaje velkými klášterními komunitami, přes lávry až po osamocené poustevníky. Co se týče vztahu pravoslavných kněží a celibátu, pak je tento stav velice výjimečný. Většina pravoslavných kněží je ženatá (oženit se musí ještě před vysvěcením), protože ženatý kněz lépe rozumí problémům ostatních a jeho rodina mu pomáhá tím, že se zapojuje do církevního dění a dává př́klad ostatním (Jeschke 1951, s. 18; Paparozzi 2010, s. 595-596; Vojtíšek 2004, s. 29). ${ }^{4}$

2 Rozhovory s římskokatolickými kněžími na téma celibát viz Bártová 2010, s. 53-102 a rozhovor s řeholní sestrou viz Bártová 2012, s. 85-94

3 Dále také např́klad McGuckin, John Anthony (2008): The Orthodox Church: An Introduction to its History, Doctrine, and Spiritual Culture. Blackwell Publishing. 474 s. ISBN: 978-1-405-15066-8

4 Rozhovor na téma celibát s protobresbyterem pravoslavné církve viz Bártová 2012, s. 104-106

\section{Řeckokatolická církev}

Řeckokatolická církev vznikla v důsledku snahy římskokatolické církve o sjednocení s Východními církvemi. Polští a litevští pravoslavní křestané, kteří usilovali o oddělení od cařihradského patriarchátu pravoslavné církve, využili této příležitosti (Vojtíšek 2004, s. 50). Do Ríma proto přijeli biskupové Hipacy Pociej a Cyryl Terlecký požádat o přijetí do římské církve na základě jednání iniciovaných roku 1594, avšak trvali na zachování vlastní liturgie a zvyklostí. Následně byli všichni členové sjednocené církve zbaveni klatby, která na nich byla od roku 1054 po velkém schizmatu. Konečně roku 1596 došlo v Brestu Litevském k podpisu Bretské unie a tím k obnovení jednoty s římskou církví. Řeckokatolická církev musela následně čelit nátlaku a snaze o opětovné sjednocení s pravoslavnou církví (Gudziak 2010, s. 178-170; Faulk 2007, s. 5-6; Franzen 2006, s. 354; iEncyklopedie). ${ }^{5}$

Pro řeckokatolickou církev je typické propojení celibátu a mnišství, avšak celibát je také chápán jako vhodný pro kněžský život. Na rozdíl od rímskokatolické církve zde ale celibát není povinný a kněží se mohou rozhodnout, zda se chtějí oženit či prožít život v celibátu. ${ }^{6}$ Tato praxe vychází z prvotní církve, kdy se kněží ženili. Rozhodnutí o tom, že kněží, jáhni a podjáhni se mohou před vysvěcením oženit, padlo již v roce 692 na Trullské synodě, avšak ten, kdo by se chtěl stát biskupem, musí zvolit život celibátní. Opačný postup, tedy nejprve vysvěcení a poté sňatek, je zcela nepřijatelný. Ženatí kněží mají být svým příkladným vedením rodiny vzorem celé komunitě (Denzler 2000, s. 26; Cheatham 2008, s. 92; Salachas 2010, s. 197). S celibátem spjaté mnišství zde má podobu spíše laického způsobu života nebot je jen velmi malý počet jeromonarchů, mnichů-kněží. Mniši mohou žít bud' o samotě jako poustevníci, ve společenství malých komunit s centrálním chrámem - lávry, či ve velkých cenobitických komunitách vedených archimandritou či igumenem (Paparozzi 2010, s. 595-596). Ač v řeckokatolické církvi převládá spíše mužské mnišství, existuje zde i ženské mnišství. Ženské mnišství prezentuje Řád svatého Basila Velikého (OSBM) neboli Baziliánky. Při vstupu do juniorátu skládají sestry dočasné sliby chudoby, poslušnosti a samozřejmě i čistoty, které jsou zhruba po pěti letech následovány sliby věčnými. Toto řeholní společenství nemá v České republice své zastoupení, avšak několik monastýrů se nachází na Slovensku (Baziliánky; Rád sestier sv. Bazila Velkého, Sestry Rádu sv. Bazila Velkého - baziliánky). ${ }^{7}$

5 Pro seznámení se základními rozdíly řeckokatolické církve od ostatních křestanských církví např: Faulk, Edward (2007): 101 Questions \&Answers on Eastern Catholic Churches. New York/Mahwah, NJ: Paulist Press. 115 s. ISBN 978-0809144419

6 Rozhovor na téma celibát s řeckokatolickým knězem viz Bártová 2012, s. 95-100

7 Rozhovor na téma celibát s řeckokatolickou řeholnicí viz Bártová 2012, s. 101-103 


\section{Protestantismus}

Protestantismus vznikal $\mathrm{v}$ průběhu reformace $\mathrm{v}$ římskokatolické církvi v 16. století. Neexistuje pouze jeden univerzální protestantismus, ale mnoho jeho různých forem. Pro všechny formy je charakteristické uznání větší autority Písma svatého než církevní tradice. Také je kladen důraz na osobní víru, avšak spásy lze, dle jejich učení, dosáhnout pouze díky Boží milosti. Oproti ř́mskokatolické církvi je praktikována zjednodušená liturgie s přijímáním svátosti těla a krve Kristovy všemi věřícími. Protestantismus rovněž odmítá mnišskou tradici a kněžský celibát. Za počátek reformace lze pokládat působení univerzitního profesora a augustiniánského mnicha Martina Luthera, který v roce 1517 uveřejnil svých 95 tezí. Lutherovým záměrem bylo vyvolat diskuzi a reformaci v rámci církve, nikoli usilovat o odtržení od církve. Navzdory tomu však došlo ke vzniku luterských církví, rozšířených v Německu a Skandinávii a následně i v zámoří. Pro luterské církve má velký význam, kromě Bib$l e$, i soubor dokumentů s názvem Kniha svornosti. Reformace se šírila celou Evropou a objevilo se množství dalších reformátorů usilujících o změnu, mezi něž patři třeba Ulrich Zwingli či Jan Kalvín ze Švýcarska. Kalvínské reformační hnutí klade důraz na Boží svrchovanost, člověk má být poslušen příkazům Bible a dbát na zbožnou praxi. Ze zásadních knih kalvinismu lze jmenovat Heidelberský Katechismus (1563) či Druhou helvetskou konfesi (1566). Ze Švýcarska se kalvinismus rozšíril do Nizozemska, Skotska a částečně do Anglie, kde byl ale brzy zatlačen anglikánskou církví, a odtud se ve formě puritánského hnutí šířil do Severní Ameriky. Jako třetí hlavní formu protestantismu lze uvést anglikánský protestantismus. Zde se v roce 1534 král Jindřich VIII. prohlásil za hlavu církve v Anglii. Anglikánská reformovaná církev se od římskokatolické církve odlišila jen málo. Prostřednictvím kolonií, se anglikánství šírilo po světě a následně vznikalo množství místně specifických forem. Spojujícím prvkem anglikánských církví je Kniha společné modlitby (MacCulloch 2005, s. 355; Metaxas 2017, s. 107; Vojtíšek 2004, s. $55-58 ; 69,71){ }^{8}$

Zaměř́me-li se na vztah protestantských církví k celibátu, je opět na prvním místě potřeba zmínit Martina Luthera. Luther procházel náboženskou úzkostí a dalo by se říci i vnitřní krizí. Situaci se snažil vyřešit pokáním a věnoval se studiu Pavlových listů Rímanům a vybraných žalmů, následně díky Pavlovu učení o ospravedlnění vírou dospěl k existenciální transformaci. Výsledkem bylo, již výše zmiňovaných, jeho 95 tezí. Luther celibát nezavrhoval, chápal ho jako prostředek napomáhající přibližení se Bohu. Dar celibátu byl podle něj Bohem udělen pouze vyvoleným jedincům, neměl tak být povinný všem, ale být pouze dobrovolný. Ti, kterým dar celibátu nebyl dán,

8 Pro hlubší poznání období reformace je vhodné rozsáhlé dílo v nejnovějším vydání jako ebook a v překladu od $\mathrm{H}$. WHITE a HENRY BEVERIDGE: Merle Draubigne, Jean Henri (2013):History of The Reformation of The Sixteenth Century. Books 1 to 20. Harrington, DE: Delmarva Publications. 690 s. nebo MacCulloch, Diarmaid (2005): The Reformation. Penguin Publishing Group: Penguin Books. 864 s. ISBN: 978-1-101-56395-3 se měli oženit, podobně jako on, když si za ženu vzal bývalou jeptišku Kateřinu z Bory, protože život v celibátu často vyústil v konkubinát, což byl podle něj horší hřích než manželství. Ulrich Zwingli, další z reformátorů, se v roce 1522 připojil k petici žádající kostnického biskupa o povolení k uzavření sňatku. Ten uzavřel v roce 1524 s vdovou, se kterou již dva roky žil. Podle Jana Kalvína se stal celibát jednou $\mathrm{z}$ nejvíce nenáviděných věcí v ř́mskokatolické církvi a neměl ani opodstatnění v Písmu, jak podle jeho argumentace dokazuje 1 Tim 4,1-5. Díky přehnanému uctívání celibátu podle něj začalo manželství ztrácet svoji svatost a důstojnost. Oproti situaci v kontinentální Evropě, kde reformátoři usilovali o odstranění povinnosti celibátu pro kněží a představitele církve, byla situace $v$ Anglii velmi odlišná. Jindřich VIII., který se s římskokatolickou církví rozešel kvůli sporu o rozvod, odmítal povolit manželství kněží a ve 30. letech 16. století zrušil veškeré kláštery, jejichž majetek si přivlastnil. Nakonec se povolení $\mathrm{k}$ uzavření sňatku dočkali i kněží anglikánské církve, nebylo to však dříve než v roce 1549 . Od počátku 20. století dochází v protestantských církvích $\mathrm{k}$ dalším změnám. Na kazatelské a další církevní pozice se začínají, na rozdíl od ostatních katolických církví, světit i ženy. Současně se však i velice pozvolně do protestantských církví vrací celibát a tak lze např́klad v Benediktinském klášteře $\mathrm{v}$ Británii nalézt anglikánského či luteránského mnicha (Abbottová 2005, s. 124; Bishop 1997, s. 96; Bryant 2008, s. 114-115,117, 119-122, 127-128; MacCulloch 2005, s. 47). ${ }^{9}$

\section{JUDAISMUS}

Judaismus nese svůj název odvozením od jména vůdce nejpočetnějšího z 12 kmenů, od Judy. Pojem judaismus neoznačuje pouze náboženství, ale i kulturní, filosofické i politické prostředí. Počátek židovského národa a jeho náboženství lze pak hledat v době vyvolení Abraháma Bohem. Přibližně ve 12 . století př. Kr. vyšli Mojžíšem vedení Abrahamovi potomci z Egypta a po čtyřicetiletém putování pouští dorazili na místo Bohem přislíbené. $\mathrm{Na}$ základě společné víry se jednotlivé hebrejské kmeny sjednotily ve společný svazek nesoucí název Izrael. Judaismus patří mezi monoteistická náboženství. Bůh, jehož jméno se z velké úcty nevyslovuje, bývá označován různými tituly, jedním z nich je např́klad Hospodin. Nejdůležitější knihou je Bible, zvaná v judaismu též Tanach. Tato kniha sestává ze tří částí: Ze Zákona, Proroků a Spisů, přičemž nejdůležitější částí je Zákon neboli Tóra (pět knih Mojžíšových). Dalším významným dílem judaismu je Talmud, sepsaná ústní tradice Mišna doplněná komentáři Gemara, který shrnuje židovskou moudrost a detailně pojednává o náboženských povinnostech (Goodman 2017, s. 8; Vojtíšek 2004, s. 130-131; iEncyklopedie). ${ }^{10}$

9 Rozhovor na téma celibát $\mathrm{s}$ protestantským kazatelem viz Bártová 2012, s. 107-110

10 Detailně se historii judaismu věnuje např. Goodman, Martin (2017): A History of Judaism. Princeton University Press. 656 s. ISBN 978-0691181271 
Pro judaismus v oblasti sexuality je typický odmítavý postoj vůči dlouhodobější sexuální zdrženlivosti a obzvláště vůči celibátu. Naopak muži i ženy se snaží vstoupit co nejdříve do manželství, nebot prostřednictvím něho vstupují i do reálného světa (Lamm 1991, s. 120). Nikdo nechce zůstat starým mládencem či starou pannou, židé se řídí Božím příkazem „Plodte a množte se a naplňte zemi“ $(\mathrm{Gn} 1,28)$ a proto je posláním každého žida zplodit potomstvo (Feder 1973, s. 109). Některými byl celibát považován až za zločin podobný vraždě, nebot bránil plození potomstva a zmenšoval tak počet Božích duší na tomto světě (Abbottová 2005, 210). Judaismus není založen na vyžadování utrpení či bolesti, ale právě naopak poukazuje na to, že k životu patří i světské radovánky. K těmto radostem života lze tedy zařadit i sexualitu, která však patř́ až do manželského života po uzavření sňatku. Pro judaismus jsou typické nejrůznější restrikce a nařízení v oblasti znečištění a očištování, to platí pro oblasti sexuality. Jako př́iklad znečištující praxe lze uvést masturbaci či soulož během menstruace. Menstruace již sama o sobě činí ženu nečistou, pokud by měl muž se ženou pohlavní styk v této době, pak by se stal také nečistým. Pro očištění je potřeba podstoupit rituální koupel v lázni mikve. U mužủ např́klad po ejakulaci spermatu (pohlavní styk, masturbace). U žen pak následuje očista rituální koupelí po skončení menstruace. Čas rituální koupele se odvozuje od délky menstruace, $\mathrm{k}$ níž se připočte dalších sedm dní na očistný rituál. Vzhledem $\mathrm{k}$ tomu, že tyto výpočty a rituály vykonává každá žena individuálně, lze takto do určité míry regulovat sexuální život (Abbottová 2005, s. 209; Diamond 2008, s. 50; Půtová 2011). Teoretická možnost sexuální zdrženlivosti slučitelná $\mathrm{s}$ židovskou tradicí je v př́padě, pakliže je to za nějakým účelem (např. při usilování o početí potomka), jakožto prostředek využitý $k$ něčemu, co je považováno za správné (Bártová 2012, s. 113). ${ }^{11}$

Navzdory tomu, že je pro judaismus primární zplození potomstva, $v$ historii lze najít př́klady i těch, které manželství a plození potomků zcela nepřitahovalo a svůj čas raději věnovali např́ílad studiu Tóry. Jedním takovým neobvyklým prŕkladem je rabín Šimon ben Azzai (2. st.), který se ostře vyjadřoval proti celibátnímu způsobu života, avšak natolik se pohroužil do studia Tóry, že prakticky celý svůj dospělý život prožil v celibátu (Abbottová 2005, s. 211; Diamond 2008, s. 52-53). V historii se také můžeme setkat s několika sektami praktikujícímu celibát. Terapeuté usilovali o dosažení asexuality a skrze ni dosažení jednoty s Bohem, v této sektě se vyskytovaly i ženy. Eséni nechtěli být vyrušování od studia a práce manželskými povinnostmi, volili život celibátní a v této sektě se ženy nevyskytovaly. Nejistá je pak situace ohledně komunity z Kumránu (někdy bývá řazena samostatně, jindy uváděna jako komunita Esénů), kde patrně žili jen muži (Diamond 2008, s. 42-45).

11 Celý rozhovor s židovským rabínem viz Bártová 2012, s. 111114

\section{ISLÁM}

Islám je řazen mezi monoteistická náboženství. Jeho vyznavači, muslimové, uctívají jediného Boha Alláha. Vznik islámu se datuje do první poloviny 7. století na území dnešní Saudské Arábie, avšak muslimové věří, že zakladatelem islámu je Alláh a doba vzniku spadá do časů Adamových. Poblíž města Mekka se zjevil archanděl Gabriel, který zvěstoval poselství od Boha, jež si měl Muhammad Ibn Abdulláh (Prorok) zapamatovat a následně zvěstovat světu. V Medině šíril Muhammad zjevené proroctví od roku 622. Následně byla v polovině 7. století Muhammadova proroctví sepsána a seřazením 114 súr, od nejkratší po nejdelší, vznikl Korán, kniha vyzívající $\mathrm{k}$ víre $\mathrm{v}$ Alláha, ale také obsahující příkazy pro každodenní život a právní oblasti života. Kromě Koránu je pro muslimy důležitá i sunna, soubor zvyklostí vycházející z hadíthů (Muhammadovy činy a výroky nezaznamenané v Koránu) či prověřených dřívějšími generacemi. Islámské právo šaría, odvozené ze sunny a Koránu, zahrnuje i náboženské povinnosti, včetně 5 pilírư islámu (šaháda, salat, saum, zakát, hadždž). Po Muhammadově smrti došlo ke sporu o následnictví, jehož následkem vznikly dva hlavní směry islámu: většinoví sunnité a menšinoví šíité. V lidové tradici se pak můžeme setkat s mystickou tradicí súfismu ('Abd al-Átí 2010, s. 22-23, 77115; Esposito 2011, s. 2, 106-113; Vojtíšek 2004, s. 301-303). ${ }^{12}$ Př́stup islámu k celibátu a sexuální zdrženlivosti je výrazně odlišný od křestanského pojetí, ale velice podobný jako v judaismu. Každý muž, vyznávající islám, který má dostatečné finanční prostředky, má uzavřít co nejdříve sňatek a založit rodinu. Pro muže je špatné se manželství vyhýbat $\mathrm{z}$ důvodu mnišského života či zasvěcení života celibátu pro uctívání Alláha, takový přístup není vítán. Stejně tak i ženy mají co nejdříve vstoupit do manželství a asketický či mnišský způsob života pro ně není určen (Abbottová 2005, s. 212; al-Qaradáwí 2004, s. 123; Bashir 2008, s. 133). V počátcích rozvoje islámu se začaly objevovat i sklony k celibátnímu životu a rozvoji mnišství. Muhammad se proto rozhodl zasáhnout a stoupence mnišství přísně napomenul, protože mnišství je odchýlením od správné cesty a odmítnutím sunny. Alláh ty, jež na sebe $\mathrm{v}$ rámci asketické praxe kladli velké nároky, přivedl do nesnází, nebot’ to byl špatný přístup (al-Qaradáwí 2004, s. 123). Prorok rovněž usměrnil i ty, jež zvažovali vzdání se manželek ve prospěch času stráveného modlitbou či půstem: „Ó vy, kdo věríte! Nezakazujte dobré věci, jež vám Alláh povolil, a neprestupujte jeho př́kazy, nebot Alláh nemiluje ty, kdo překračují meze Jím stanovené. " (5:87). Oni tak ustoupili od svého úmyslu, nebot správná cesta vede středem bez vybočování do extrémů (Abu Bakr Siraj Ed-Din 2008, s. 418-419; al-Qaradáwí 2004, s. 123-124). Z období středověku uvádí

12 Pro hlubší poznání počátků islámu či islámské teologie jsou vhodné např́klad Nasr, Seyyed Hossein (2008): Islamic Spirituality: Foundations. London: Routledge \& Kegan Paul. 480 s. ISBN 978-0415-44262-6 a další jeho publikace nebo Schmidtke, Sabine (2016): The Oxford Handbook of Islamic Theology. Oxford: Oxford university press. 828 s. ISBN 978-0-19-969670-3 
Bashir (2008) argumentaci Muhammada al-Ghazzaliho (učenec a autor pojednání o manželství a celibátu), že Bůh byl schopen stvořit člověka bez sexuální tužby a reprodukčních orgánů, ale neučinil tak a proto zde neexistuje žádné opodstatnění pro celibátní život.

Ačkoli se islám k celibátu a sexuální zdrženlivosti staví odmítavě a velmi negativně, lze $\mathrm{v}$ něm určitou formu zdrženlivosti či sexuální abstinence nalézt. Tato forma zdrženlivosti je spjata s mnoha náboženskými povinnostmi, hlavně však se dvěma pilírii: s půstem během měsíce ramadánu (saum) a s poutí do Mekky (hadždž). Během měsíce ramadánu dodržují všichni dospělí muslimové kromě přísného půstu od jídla, pití a kouření také naprostý sexuální půst v době od rozbřesku do soumraku po celý měsíc. Každý, kdo koná velkou pout do Mekky či jen malou pout Umra, se nachází ve stavu rituálního posvěcení ihrám. Pro dosažení tohoto stavu je potřeba rituální očistění, kromě mnoha nařízení týkajících se úpravy vlasů a dalších částí těla je součástí i zákaz lovu a sexuální aktivity ('Abd al-Átí 2010, s. 102, 111-112; Bashir 2008, s. 136; Esposito 2011, s. 110-112). Zabýváme-li se vztahem islámu k celibátu, pak nelze vynechat súfismus, který se začal rozvíjet nedlouho po Prorokově smrti (632) jako mystická forma islámu v praxi spojená se zřeknutím se materiálních potřeb a ovládáním sexuálních tužeb sexuální zdrženlivostí, př́ípadně celibátní praxí. Slib celibátu měl zcela odlišný význam pro muže a ženy. $U$ mužů se jednalo většinou o snahu omezit sexuální touhu, pro ženy to však byl způsob jak získat větší moc sama nad sebou a postavením se dostat na úroveň mužů. Typickým prŕkladem je Rabia al-Adawiyya, která byla jako dítě prodána do otroctví, avšak od mládí projevovala mimořádné sklony $\mathrm{k}$ asketismu, díky čemuž ji její majitelka osvobodila a svobodná Rabía prožila téměř celý svůj dospělý život náboženským snažením (Abu Bakr Siraj Ed-Din 2008, 411-436; Bashir 2008, s. 135-137, 140-141). V pozdějších letech se súfismus rozvinul v mnoho odlišných forem. Jako př́klad lze uvést skupinu asketických poutníků Qalandars či skupinu, kterou založil Qutb al-Din Haydar, jež se vyznačuje nošením kovových límců, náramků a zvonků a někteří její členové si své genitálie propichují kovovými kroužky. Nedílnou součástí pro dosažení vyššího postavení v řádu Bektaši se stal celibát. Tato forma súfismu se udržela v Albánii a Baba neboli mistr žijící v celibátu, byl rozpoznatelný díky speciální náušnici, kterou obdržel při uvedení do úřadu (Bashir 2008, s. 141-144; Nguyen 2016, s. 339). Většinoví muslimové nepovažují súfismus za něco vítaného a hlavní proud islámu se súfismu spíše straní (Bártová 2012, s. 120). ${ }^{13}$

\section{HINDUISMUS}

Hinduismus je spíše než náboženství společensko-náboženský systém, který sestává $\mathrm{z}$ náboženských a filosofických tradic, náboženských praktik a sociálních zvyklostí. Počátek hinduismu se klade přribližně do poloviny 1 . tisíciletí př̀. n. l., kdy

13 Více o pohledu dnešních muslimů k otázce celibátu viz Bártová 2012, s. $115-126$ se vyvinul z původního védského náboženství, avšak některé prvky pocházejí z ještě starších kultur. Název hinduismus je odvozen od perského slova hind a označuje oblast údolí řeky Indus, někteří vyznavači používají namísto názvu hinduismus označení Sanátana Dharma (věčný řád). Tento věčný řád určuje na základě rodového původu postavení člověka ve společnosti. Existuje velké množství i místně specifických forem hinduismu, mezi nejvýznamnější patří višnuismus a šivaismus. Nejstarším zdrojem informací jsou védské texty šruti (zjevené slovo) původně předávané ústní tradicí bráhmanskými rodinami. Mezi další významné texty patří třeba upanišady, bráhmany, sútry, purány a eposy Rámájana a Mahábhárata s knihou Bhagavadgíta. Podstatou hinduismu je víra ve věčný životní koloběh sansára, při němž dochází k nekonečnému převtělování átmanu, duše. Převtělování je ovlivněno působením zákona karmy, každé jednání má své následky, před kterými se nelze skrýt. $\mathrm{V}$ rámci tohoto koloběhu má důležitou roli systém čtyř varn $\mathrm{z}$ nichž nejvýše postavenou jsou brahmáni, následují kšátrijové, vaišjové a šúdrové, mimo tyto varny existuje ještě speciální skupina nedotknutelných, která je nejníže postavená. Cílem každého člověka je vymanit se z tohoto koloběhu a dosáhnout mókši, duchovního osvobození, a splynutí duše átman s vesmírným duchem brahma (Flood 2003, s. 2-3; Filipský, 2011; Chadima 2009, s. 103; Waterstone 1996, s. 16-17, 24).

Pojem celibát či sexuální zdrženlivost v sanskrtu asi nejlépe vystihuje výraz brahmačarja. $\mathrm{V}$ původním slova smyslu označoval tento pojem mladého chlapce, který se věnoval mnoho let studiu véd. U takovýchto studentů se očekávalo, že budou žít zdrženlivým či celibátním způsobem života. $\mathrm{V}$ pozdější době pak tento termín začal označovat i indické askety (Abbottová 2005, s. 182; Bellinger 1998, s. 149; Olivelle 2008, s. 152). Původní rané védské náboženství asketismus neznalo. Podle véd bylo za dob původních bráhmanů ideálem zbožného života uzavření manželství, kterým se muž stal kompletním a znovu se tak zrodil. Asketismus (tapas) patrně vznikl kombinací bráhmanismu s rozličnými nebráhmanskými vlivy, mezi něž lze také počítat vznikající nová náboženství: buddhismus a džinismus. Společně s rozvojem celibátu se začaly rozdělovat názory na něj. Někteří chápali celibát jako prostředek $\mathrm{k}$ vnitřnímu rozvoji původních védských rituálů, avšak jiní ho považovali naopak za odklon od původních védských náboženských hodnot (Michaels 2004, s. 315 Olivelle 2008, s. 153-156; Werner 2005, s. 25). Každý člověk ve svém životě usiluje o dosažení mókši, $\mathrm{k}$ čemuž vede čtyřdílná cesta. Tato životní cesta je převážně určena mužům, jen velmi malé procento žen se jí vydává. První období, období usilovného studia véd a sexuální zdrženlivosti, se jmenuje brahmačarja. Pokud mladík při studiu podlehl svým sexuálním touhám, čekala ho náročná pokání. Druhé období grhasthja představuje život hospodáře, muž se má věnovat své manželce, dětem a kariéře a manželé si mají náležitě užívat svoji sexualitu. Během třetího období vánaprasthja se člověk cvičí v odříkání a odchází do lesa, kde se živí pouze kořínky, zeleninou a ovocem, neustále také recituje texty véd. Jen málo jedinců vstupuje do této fáze. V posledním čtvrtém období sannjása, jehož 
dosahuje jen velmi malé množství lidí, se člověk plně věnuje asketickému životu. Sanjásin už nemá žádné pozemské cíle, je poutníkem bez majetku a povinností a živí se $\mathrm{z}$ almužen. Pokud se askezi věnujíi ženy, pak se nazývají sádhví. Poznávacím znakem tohoto stádia jsou okrově žlutá roucha a dlouhé, většinou neupravené, vlasy. Sanjásini mohou žít bud’ samostatně anebo $\mathrm{v}$ rádech. Jedním takovým je řád rámánandiů. Jeho členové pocházejí ze všech kast a dříve mezi sebe přijímali i ženy, to však dnes již neplatí. Každý člen si vybere svého guru $\mathrm{z}$ jednoho ze tří podřádů: tjáginové, nágové a rasikové. Tjáginové putují ve skupinách venkovem a v rámci zachování celibátu se uchylují i ke kastraci. Nágové se věnují vojenskému výcviku a zápasení. Celibát je pro ně nezbytným předpokladem fyzického tréninku a uchování spermatu je stěžejní pro duchovní sílu. Rasikové se soustředujív trvalých chrámových komunitách. Věří, že jejich nahromaděné sperma dokáže změnit jejich mužskost $\mathrm{v}$ ženské kvality, někteří dokonce nosí dámské šaty. Sádhuové, svatí muži a jogíni, kteří žijí osamoceně, věří, že díky asketickému životu se jim podaří prohlédnout skrze máju (iluzi) a tak poznat pravou božskou realitu. Důležitou roli v askezi má jóga, která je prostředkem ke zklidnění a vnitřní očistě (Abbottová 2005, s. 181-186; Michaels 2004, s. 315; Waterstone 1996, s. 70; 82; 84-87) Hinduismus má, na rozdíl od ostatních náboženství, fyzickou dimenzi celibátu a tou je sperma. Tato životodárná tekutina je podstatou života. Je to sedmá a nejvyšší tělesná esence, zdroj vnitřní síly a energie. V některých upanišadách se nad její ztrátou truchlí jako nad určitým druhem smrti. Sexuální zdrženlivost brání jejímu plýtvání a díky tomu se kumuluje tvưrčí energie zvyšující intelekt, fyzickou výdrž a dokonce se lze setkat is tvrzením, že umožňuje číst myšlenky či nahlížet do budoucnosti (Abbottová 2005, s. 178-179, 183; Olson 2008, s. 165; Wujastyk 2003, s. 399$).{ }^{14}$ Co se týče ženské asketické praxe, již byly zmiňovány sádhví (mnišky). Avšak na ženy je často pohliženo jako na bytosti snadno podléhající vášním a proto nevhodné pro zbožné poslání. Navíc ženy nejsou schopny produkovat a hromadit sperma, tudíž se nikdy nemohou dostat na úroveň mužů. Přesto se někdy můžeme setkat s názorem, že menstruační krev či mateřské mléko jsou ekvivalentem spermatu. Zmínit si zaslouží i Dcery Brahmy, Brahmakumárí, náboženská společnost založená ve 30 . letech 20. století klenotníkem Lekhradžem, která sdružuje ženy (dnes i muže) a důležitá je síla celibátu nikoli spermatu (Abbottová 2005, s. 186-190; Wujastyk 2003, s. 399). ${ }^{15}$

\section{BUDDHISMUS}

Podobně jako u hinduismu se nejedná o náboženství jako takové. $\mathrm{V}$ tomto prípadě jde spíše o nábožensko-filosofický směr, který má mnoho forem. $\mathrm{V}$ buddhismu, který vznikal asi

14 Rozhovor na téma celibát $\mathrm{s}$ jogínem viz Bártová 2012 s. 127-131

15 K problematice asketismu žen v hinduismu viz. Denton, Lynn Teskey (2004): Female Ascetics in Hinduism. State University of New York Press v 6. století př̀. n. 1., je kladen důraz spíše na samotné učení než na konkrétní postavu zakladatele či stvořitele. Za jeho zakladatele je považován princ Siddhárta Gautama, který ve svých zhruba třiceti letech opustil dosavadní způsob života a začal se snažit $o$ vymanění $\mathrm{z}$ věčného koloběhu znovuzrození. Extrémní askezí, ke které se upnul, se mu úspěchu dosáhnout nepodařilo a tak se uchýlil $\mathrm{k}$ meditaci. Po čtyřiceti devíti dnech meditace dospěl $\mathrm{k}$ objevu správné, střední, cesty vyhýbající se krajnostem, dosáhl osvícení a od té doby byl znám jako Buddha Šákjamuni. Základem učení je víra v reinkarnaci (převtělování), každý člověk prožívá nekonečný cyklus existencí (sansára) a na základě činů, které jsme vykonali během života, nám karma určí, jak se zrodíme v následujícím životě. Dủležitým prvkem je rovněž meditace, která je nezbytná pro dosažení vnitřní svobody a následně nirvány. Základem učení se staly čtyři vznešené pravdy. První nám sděluje, že život je plný strastí, druhá udává, že původem těchto strastí jsou naše touhy, třetí pravda pojednává o tom, že strast zaniká spolu s našimi touhami a konečně čtvrtá pravda odhaluje osmidílnou cestu, která vede $\mathrm{k}$ zániku strasti a vrcholí ukončením koloběhu znovuzrození a nirváně. V buddhistickém učení hrají velkou roli také trri drahokamy: Buddha, dharma a sangha. $Z$ různých forem buddhismu lze uvést například théravádový buddhismus (též hínajána), mahajána (nejrozšířenější forma), vadžrajána (tantrický buddhismus) z nějž se vyvinul tibetský buddhismus či zenbuddhismus (Abbottová 2005, s. 190-191; Bellinger 1998, s. 166-169; Dufour 2007, s. 7-10; Harvey 2013, s. 2; Kolmaš, 2011; Waterstone 1996, s. 34-35) ${ }^{16}$

Buddhovi následovníci se sdružovali a začali vytvářet společenství mnichů či mnišek zvaná sangha. Život v klášterních komunitách se řídí Vinajou, souborem textů obsahující definice etických standardů, každodenního chování a trestů za porušení, platných pro hínajánu i mahajánu. Existují dvě fáze zasvěcení života. Novicové skládají deset hlavních slibů (společných mnichům i laikům) a pět slibů závazných pouze mnichům. V druhé fázi následoval obřad spojený se zkouškou, po jejichž absolvování se uchazeč stával mnichem, tzv. bhiksu a zavazoval se dodržovat dalších dvě stě předpisů. Mnišky, bhiksuni, musely dodržovat přes tři sta předpisů, př̀ičemž většina ze sta přidaných předpisů se týkala zdrženlivého života. Tento soubor pravidel pro mnichy a mnišky se nazývá prátimókša. Z pravidel pro mnichy lze uvést zákaz zdržování se v uzavřeném prostoru o samotě se ženou či setkání se se ženou v ústraní, kde by je ostatní neslyšeli, dále i zákaz homosexuálních styků či sexuálních styků se zvířaty. Mnichům i mniškám je společný zákaz sebeuspokojování. Mnišky mají usilovat o potlačení sexuality zbavením se ženských rysů, holí si hlavy, stř́́dmě se stravují, čímž získávají téměř chlapecké postavy a nařasený oděv skrývá zbytek ženských rysů. Mezi provinění mnišek patřilo pěstování sexuálních vztahů či in-

16 Pro detailnější výklad odborných pojmů viz. Buswell Jr., Robert E. (2004): Encyclopedia of Buddhism. MacMilan References USA nebo Buswell Jr., Robert E. - Lopez Jr., Donald S. (2014): The Princeton Dictionary of Buddhism. Princeton and Oxford: Princeton University Press 
trikování kvůli schůzce, pakliže si mnišky vypomáhaly, čekaly všechny stejné postihy. Nejhorším trestem pro mnichy i mnišky bylo vyhnání z kláštera (Abbottová 2005, s. 193-195; Dufour 2007, s. 16; Johnston 2013, s. 264; Kabilsingh 1998, s. 17; Powers 2008, s. 203; 206-207). V theáravádovém buddhismu může nirvány dosáhnout pouze člen sanghy, proto rodiče posílají své syny do kláštera. Při vstupu dostávají chlapci šafránově žluté roucho, misku na almužnu a oholí jim vlasy. Asi v osmi letech obdrží první svěcení nazvané vykročení. Ve dvaceti letech může být mnich vysvěcen trvale a zavazuje se dodržovat všech 227 pravidel. Adeptky na mnišky musí $\mathrm{v}$ př́padě, že jsou mladší dvaceti let nebo byly vdané déle než 12 let, projít dvouletou zkušební dobou. Pro mnichy představovaly ženy velké pokušení a tak jim jako pomůcka pro omezení touhy mělo pomáhat představovat si každou ženu jako svoji matku, sestru či dceru, př́ípadně si svůj objekt zájmu představovat $\mathrm{v}$ různých stádiích rozkladu. Rovněž se prísně postili a meditovali, což jim napomáhalo se bránit pokušení (Abbottová 2005, s. 195; Johnston 2013, s. 263-264; Powers 2008, s. 207-208; Wanguová 1996, s. 105-106; 195). Pro tibetský buddhismus je typický rozličný př́stup k celibátu v průběhu věků. $\mathrm{V}$ počátcích celibát nehrál důležitou roli, ale později, společně s rozvojem klášterů, začal být vyžadován. Následný trvalý úpadek klášterní morálky a nedodržování celibátu ukončil až reformátor Congkhapa, který shromáždil roztroušeně žijící mnichy do klášterů a nařídil přísně dodržovat celibát. $\mathrm{V}$ japonském zenbuddhismu, který měl vliv i na korejský, se můžeme naopak setkat $s$ velkým počtem ženatých kněží, rozšiř̌ná je zde i homosexualita, celibát zde dodržují mniši žijící ve společenstvích (Bishop 1997, s. 71; Kieschnick 2008, s. 231-235, 237; Kolmaš, 2011; Powers 2008, s. 217). ${ }^{17}$

\section{ZÁVĚR}

Na světě existuje velké množství rozlišných náboženství, která přistupují $\mathrm{k}$ problematice sexuální zdrženlivosti a celibátu odlišným způsobem. $\mathrm{V}$ této studii jich bylo představeno pět nejrozšiřrenějších: křestanství, judaismus, islám, hinduismus a buddhismus. Existují však mnohá další náboženství, kterým zde bohužel $\mathrm{z}$ důvodu rozsahu nemohl být dán prostor, mezi něž patř́i např́ílad konfucianismus, taoismus, džinismus a další. Ze tří uvedených monoteistických náboženství mají dvě, judaismus a islám, zcela negativní pohled na celibát, avšak lze se $\mathrm{v}$ nich setkat $\mathrm{s}$ určitou formou sexuální zdrženlivosti. V křestanství a buddhismu má celibát svoji pevně danou pozici v rámci klášterního života, př́padně církevní hierarchie. V hinduismu je celibát spjat hlavně s askety, ale měl by být i součástí běžného života. $Z$ dostupných informací lze usoudit, že v náboženstvích, která mají celibát pevně zakotvený, se objevují snahy o jeho odstranění (nejvýrazněji

17 Rozhovor na téma celibát $\mathrm{s}$ buddhistou viz. Bártová 2012, s. 132-137 a rozhovory se zástupci buddhismu v České republice viz Honzík, Jan (2010): Jednota v rozmanitosti: Buddhismus v České republice. Dharma Gaia. v rrímskokatolické církvi) a naopak v náboženstvích, která celibát odmítají se lze $\mathrm{v}$ jejich historii setkat se snahami o jeho zavedení, $\mathrm{v}$ islámu se jedná o súfismus a u judaismu lze uvést např́iklad Esény. Každé náboženství během své historie prodělalo četné změny a tak lze jen těžko odhadnout, jakým směrem se bude jejich vztah $\mathrm{k}$ regulaci sexuality vyvíjet nadále. To co je dnes v otázce celibátu, prŕpadně sexuální zdrženlivosti trvalé a neměnné se může $\mathrm{v}$ budoucnosti zcela změnit. To však ukáže až čas.

\section{PODĚKOVÁNÍ}

Chtěla bych poděkovat za cenné rady svému školiteli prof. PhDr. Jaroslavu Malinovi, DrSc. a všem respondentům, kteř́ se rozhodli poskytnout svůj rozhovor. Rovněž si můj veliký dík zaslouží kolegové, kteří mi poskytli pomoc, a to nejen morální.

\section{LITERATURA}

Abbottová, Elizabeth (2005): Historie celibátu. Praha: BB/art

'Abd al-Átí, Hammudah (2010): Zaostřeno na islám. Ústředí muslimských obcí

Abu Bakr Siraj Ed-Din (2008): The Nature and Origin of Sufism. In Nasr, Seyyed Hossein (ed.): Islamic Spirituality: Foundations. London: Routledge \& Kegan Paul. s. 411-436.

Al-Qaradáwí, Júsuf (2004): Povolené a zakázané v Islámu. Praha: Islámská nadace

Baret, Daniel (2017): Papež prý řekl, že se má zrušit celibát. Bylo by to šokující, kdyby to tak řekl, ale neřekl. (online) http://www.reflex.cz/clanek/zpravy/78123/papez-pry-rekl-ze-se-ma-zrusit-celibat-bylo-by-to-sokujici-kdyby-to-tak-rekl-ale-nerekl.html

Bártová, Věra (2010). Celibát ř́mskokatolických kněží. Bakalářská práce. Brno: Př́rodovědecká fakulta, Masarykova univerzita

Bártová, Věra (2012). Celibát v náboženstvích světa: komparativní antropologická studie. Diplomová práce. Brno Př́rodovědecká fakulta, Masarykova univerzita

Bible, Český ekumenický překlad. (2002): Česká biblická společnost

Bashir, Shahzad (2008): Islamic Tradition and Celibacy. In Olson, Carl (ed.): Celibacy and religious traditions. Oxford: Oxford university press. s. $133-150$.

Baziliánky (Rád sestier sv. Bazila Velkého v SR). In rehole.sk (online) https:// www.rehole.sk/detaily.php?d=40

Bellinger, Gerhard J. (1998): Sexualita v náboženstvích světa. Praha: Academia Bishop, Clifford (1997): Lidský duch a sexualita. Praha: Knižní klub/ Práh

Bowie, Fiona (2008): Antropologie náboženství. Praha: Portál

Blumenthal, Uta-Renate (2008): The Prohibition of clerical marriage in the eleven century. In Deusen, Nancy van. (ed.) Chastity : a study in perception, ideals, opposition. Leiden, Boston: Brill. s. 61-65.

Bryant, M. Darrol (2008): Celibacy and protestant traditions: From celibacy to the freedom of the christian. In Olson, Carl (ed.): Celibacy and religious traditions. Oxford: Oxford university press. s. 109-131.

Denzler, Georg (1999): Zakázaná slast : dva tisíce let křestanské sexuální morálky. Brno: Centrum pro studium demokracie a kultury

Denzler, Georg (2000): Déjiny celibátu. Brno: Centrum pro studium demokracie a kultury

Diamond, Eliezer (2008): „And Jacob Remained Alone“: The Jewish Struggle with Celibacy In: Olson, Carl (ed.): Celibacy and religious traditions. Oxford: Oxford university press. s. 41-64.

Dufour, Jean-François (2007): Buddhismus. Praha: Levné knihy KMa

Elliot, Dyan (1999): Fallen bodies pollution, sexuality and demonology in the Middle Age. Philadelphia: University of Pensylvania Press 
Esposito, John L. (2011): Islam: The Straight Path. Oxford, New York: Oxford University Press

Faulk, Edward (2007): 101 Questions \&Answers on Eastern Catholic Churches. New York/Mahwah, NJ: Paulist Press

Feder, Richard (1973): Život a odkaz, Praha: Ústřední církevní nakladatelství

Filipský, Jan (2011): Hinduismus. In Malina, Jaroslav: Encyklopedie antropologie. Brno: Masarykova univerzita, (online) http://is.muni.cz/elporta$1 /$ ?id $=962501$

Flood, Gavin (2003): Introduction: Establishing the Boundaries. In Flood, Gavin: The Blackwell Companion to Hinduism. Blackwell Publishing Ltd. s. $1-19$

Franzen, August (2006): Malé dějiny církve. Kostelní Vydř́i: Karmelitánské nakladatelství

Goodman, Martin (2017): A History of Judaism. Princeton University Press

Gudziak, Boris (2010): Brest-litevská unie. In Farrugia, Edward G.: Encyklopedický slovník křestanského Východu. Olomouc: Refugium Velehrad-Roma. s. 178-179

Hackel, Sergej (2010): Pravoslavná církev, struktura a kul. In Farrugia, Edward G.: Encyklopedický slovník křestanského Východu. Olomouc: Refugium Velehrad-Roma. s. 714-716

Harvey, Peter (2013): An Introduction to Buddhism: Teaching, History and Practise. Cambridge University Press

Heid, Stefan (2000): Celibacy in the Early Church: The Beginnings of a Discipline of Obligatory Continence for Clerics in East and West. Ignatius Press

Holland, Glenn (2008): Celibacy in the Early Christian Church. In: Olson, Carl (ed.): Celibacy and religious traditions. Oxford: Oxford university press. s. $65-83$

Chadima, Martin (2009): Dějiny erotiky a sexuality v náboženství. Hradec Králové: Gaudeamus

Cheatham, Karen (2008): „Let anyone accept this who can“: Medieval christian virginity, chastity, and celibacy in the latin west. In Olson, Carl (ed.): Celibacy and religious traditions. Oxford: Oxford university press. s. 85-107.

Cholij, Roman (1993): Priestly celibacy in patristics and in the history of the Church. (online) http://www.vatican.va/roman_curia/congregations/ cclergy/documents/rc_con_cclergy_doc_01011993_chisto_en.html

Jeschke, J. B. (1951): Knižka o Pravoslaví. Praha: Kalich

Johnston, William M. (2013): Encyclopedia of Monasticism. Routledge. Taylor \& Francis Group

Jung, Carl Gustav (1994): Duše moderního člověka. Brno : Atlantic

Kabilsingh, Chatsumark (1998): Women in Buddhism: Questions and Answers. Faculty of Liberal Arts, Thammasat University

Karmelitánské nakladatelství: iEncyklopedie.cz. (online) www.iencyklopedie. $\mathrm{cz}$

Katechismus katolické cirkve. (2002): Kostelní Vydří: Karmelitánské nakladatelství

Kieschnick, John (2008): Celibacy in East Asian Buddhism. In Olson, Carl (ed.): Celibacy and religious traditions. Oxford: Oxford university press. s. $225-240$.

Kolmaš, Josef (2011): Tibetský buddhismus. In Malina, Jaroslav: Encyklopedie antropologie. Brno: Masarykova univerzita, (online) http://is.muni. $\mathrm{cz} /$ elportal/?id=962501

Lamm, Maurice (1991): The jewish way in love \& marriage. New York: Johnatan David Publishers

MacCulloch, Diarmaid (2005): The Reformation. Penguin Publishing Group: Penguin Books

Malina, Jaroslav - Pardyová, Marie - Pavelka, Jiří (2011): Křestanská civilizace. In. Malina, Jaroslav: Encyklopedie antropologie. Brno: Masarykova univerzita, (online). http://is.muni.cz/elportal/?id=962501

Metaxas, Eric (2017): Martin Luther: The Man Who Rediscovered God and Changed the World. Viking

Michaels, Axel (2004): Hinduism: Past and Present. Princeton: Princeton University Press
Nguyen, Martin (2016): Sufi Theological Tought. In Schmidtke, Sabine (ed.) The Oxford Handbook of Islamic Theology. Oxford: Oxford university press. s. $325-346$.

Olivelle, Patrick (2008): Celibacy in Classical Hinduism. In Olson, Carl (ed.): Celibacy and religious traditions. Oxford: Oxford university press. s. 151-164.

Olson, Carl (2008): Hindu Devotionalism, Tantra, and Celibacy. In Olson, Carl (ed.): Celibacy and religious traditions. Oxford: Oxford university press. s. 201-224

Powers, John (2008): Celibacy in Indian and Tibetan Buddhism. In Olson, Carl (ed.): Celibacy and religious traditions. Oxford: Oxford university press. s. 201-224.

Paparozzi, Maurizio (2010): Mnišství. In Farrugia, Edward G.: Encyklopedický slovník křestanského Východu. Olomouc: Refugium Velehrad-Roma. s. 595-597.

Parish, Helen (2010): Clerical Celiacy in the West: c. 1000-1700. Routledge Taylor \& Francis Group

Pavel VI. (1965a): Optatam totius, Dekret o výchově ke kněžství. (online) http://www.vatican.va/archive/hist_councils/ii_vatican_council/documents/vat-ii_decree_19651028_optatam-totius_cs.html

Pavel VI. (1965b): Presbyterorum ordinis, Dekretoživotěa služběkněží. (online) http://www.vatican.va/archive/hist_councils/ii_vatican_council/documents/vat-ii_decree_19651207_presbyterorum-ordinis_cs.html

Pavel VI. (1967): Sacerdotalis caelibatus, Encyclical of pope Paul VI on the celibacy of the priest. (online) http://w2.vatican.va/content/paul-vi/en/ encyclicals/documents/hf_p-vi_enc_24061967_sacerdotalis.html

Phipps, William E. (2004): Clerical Celibacy: The Herritage. Bloomsbury Publishing. Continuum

Půtová, Barbora (2011): Mikve. In. Malina, Jaroslav: Encyklopedie antropologie. Brno: Masarykova univerzita, (online). http://is.muni.cz/elporta$1 /$ ?id=962501

Rád sestier sv. Bazila Velkého (online) http://bazilianky.wbl.sk

Roberson, Ronald G. (2010): Pravoslavná církev, vzájemné společenství a autokefalie. In Farrugia, Edward G.: Encyklopedický slovník krestanského Východu. Olomouc: Refugium Velehrad-Roma. s. 716-717

Salachas, Dimitrios (2010): Celibát. In Farrugia, Edward G.: Encyklopedický slovník krestanského Východu. Olomouc: Refugium Velehrad-Roma. s. 197.

Selin, Gary (2016): Priestly Celibacy: Theological foundations. The Catholic University of Americy Press

Stickler, Alfons Maria (1995): The Case for Clerical Celibacy: Its Historical development \& Theological Foundations. Ignatius Press.

Sestry Rádu sv. Bazila Velkého - baziliánky (online) http://www.bazilianky.sk

Vojtišek, Zdeněk (2004): Encyklopedie náboženských směrů: náboženství, církve, sekty, duchovni společenství. Praha: Portál

Wanguová, Madhu Bazuz (1996): Buddhismus. Praha: Nakladatelství Lidové noviny

Waterstone, Richard (1996): Duchovní svět Indie. Praha: Knižní klub

Werner, Karel (2005): A Popular Dictionary of Hinduism. Curzon

Wujastyk, Dominik (2003): The Science of Medcine. In Flood, Gavin: The Blackwell Companion to Hinduism. Blackwell Publishing Ltd. s. 393-409.

\section{AUTORKA}

Bártová, Věra (27. 11. 1987, Brno) doktorská studentka antropologie na Masarykově univerzitě v Brně věnující se problematice antropologie, náboženství a sexuality. Rovněž vystudovala i bakalářské studium Teologických nauk na Cyrilometodějské teologické fakultě Univerzity Palackého v Olomouci. Je členkou České společnosti antropologické, účastní se mezinárodních konferencí a publikuje vodborných periodicích. 
